\title{
Wechsler's Century and Ours: Reforming Criminal Law in a Time of Shifting Rationalities of Government
}

\author{
Jonathan Simon $\uparrow$
}

If we are to avoid dictatorship, we must be content to face problems that are of trivial importance to a dictator. ${ }^{1}$

\section{INTRODUCTION: HERBERT WECHSLER AND THE 20TH CENTURY}

Herbert Wechsler, who died in 2000 at over 90 , led a life in the law that could well define the legal twentieth century in America. Students today might first encounter him as a constitutional scholar whose article "Toward Neutral Principles of Constitutional Law"2 was for decades discussed as the most principled intellectual criticism of the Supreme Court's greatest twentieth century decision, Brown v. Board of Education. ${ }^{3}$ Wechsler was one of the leading exponents of the legal process school that dominated academic law in the 1950s and 1960s. ${ }^{4}$ Along with Herbert Hart, Wechsler was the original co-author of the most influential casebook in that quintessentially

$\dagger$ Professor of Jurisprudence and Social Policy, Boalt Hall, School of Law, UC Berkeley.

1. Herbert Wechsler, A Caveat on Crime Control, 27 J. Am. Inst. Crim. L. \& Criminology 629, 633 n.6 (1937) [hereinafter Caveat].

2. Herbert Wechsler, Toward Neutral Principles of Constitutional Law, 73 Harv. L. Rev. 1 (1959).

3. 347 U.S. 483 (1954).

4. Harold Edgar, Herbert Wechsler and the Criminal Law: A Brief Tribute, 100 Colum. L. Rev. 1347, 1355 (2000). Avowed admirers of the legal process school in the current faculty of American law schools today are few. Like other dominant academic theories of the post-World War II period, it often seems tainted by having co-existed with national security hysteria in the political mix of that day, but there is one point at least on which I for one would want to wholly affirm the legal process school, and that was its focus on law as a form of governance, and of legal expertise as a form of expertise about governance. 
twentieth century legal sub-field "federal courts." Wechsler served as the reporter for the Model Penal Code, ${ }^{6}$ which since the 1960s has served as the most influential source of modern criminal law reform thought for American scholars and state legislatures. ${ }^{7}$ His casebook on criminal law, coauthored with Jerome Michael, became the template for all contemporary criminal law casebooks and perhaps the modern casebook more generally. ${ }^{8}$ A teacher at Columbia Law School for over half a century, Wechsler also helped define the role of the law professor in the post-World War II legal academy and influenced its relationship with other institutions including the social sciences and government.

In this essay I want to draw on Wechsler in the 1930s, when his approach to criminal law (and I would speculate his view of law more generally) entered into its public form, to reflect on the criminal law at moments of history when the very rationality of government, ${ }^{9}$ i.e., the forms of knowledge and the mechanisms of power through which political authority is exercised, is undergoing radical transformation. After defending briefly the claim that we are in a moment that parallels the transformational possibilities of the $1930 \mathrm{~s}$, I want to compare governmental challenges facing Wechsler's criminal law reform project to the possibilities of reform today.

There is little serious doubt that the 1930s, marked by the Great Depression and Franklin Roosevelt's New Deal response to that crisis, produced a fundamental transformation in the forms and means of government. Whether one views this primarily as a regime change, a

5. Henry Melvin Hart \& Herbert Wechsler, The Federal Courts and the Federal System (1953).

6. Model Penal Code (Proposed Official Draft 1962).

7. Sanford H. Kadish, Fifty Years of Criminal Law: An Opinionated Review, 87 Cal. L. Rev. 943, 946 (1999).

8. Herbert Wechsler \& Jerome Michael, Criminal Law and its Administration; Cases, Statutes, and Commentaries (1940).

9. I mean government here in Michel Foucault's sense of a form of power that has as its object other relations of power. See 3 Michel Foucault, Governmentality, in Essential Works of Foucault, 1954-1984 201 (James D. Faubion ed., 2000). 
shift in the economic order, a recasting of political rationalities, or a constitutional moment, ${ }^{10}$ there is broad consensus among political scientists, historians, sociologists, and lawyers that the 1930s marked a fundamental transformation in American government.

The 1920s saw its own revolution in the governance of social organizations at all levels from families and farms through huge corporations. New technologies like radio, the automobile, and electricity encouraged new models of management and raised new regulatory concerns for political government. ${ }^{11}$ In Europe as well, the aftermath of World War I and the massive economic and social destruction it led to led to dramatic changes in governance at all levels. ${ }^{12}$ The worldwide depression that swept through the industrial economies starting in 1929 had by the 1930s entrenched itself, bringing cataclysmic levels of unemployment across both city and farmland, with resulting privation and social disorganization.

In the United States as in Europe, new leadership responded to the crisis. Both Hitler and Roosevelt, each of whom assumed national executive leadership in 1933, appeared at first as traditional politicians but then introduced radical change in the nature of government. Although it built upon important precedents developed in the Progressive era, Roosevelt established a new paradigm of power at the federal level that in time came to work at the state and local levels as well. At the heart of this paradigm was a social conception of governance in which the proper target of government was not individuals but social groups whose interdependence must be made visible and coordinated by government. The legalization of labor unions, the adoption of a national system of social insurance, the expansion of the role of public spending as a fiscal stimulus of the economy, and the imposition of new regulatory controls over private enterprise were all aspects

10. Bruce A. Ackerman, We the People: Transformations (1998).

11. Morton Keller, Regulating a New Society: Public Policy and Social Change in America, 1900-1933 (1994).

12. Charles S. Maier, Recasting Bourgeois Europe (1975). 
of this paradigm. While its critics viewed the New Deal as a step toward socialism, it in fact offered a competing strategy of recognizing the social context of individual freedom in capitalist society.

Although less clearly focused than the model of the Great Depression and the New Deal, the period since the 1970 s can be seen as marking a break with the New Deal approach to government. ${ }^{13}$ The election of Ronald Reagan in 1980 (and a few years earlier, Margaret Thatcher in Great Britain) was also a response to an economic crises in the advanced post-industrial economies (albeit one not nearly as devastating as the 1930s) that was taken as a sign of fundamental weakness in the capacity of New Deal style government to foster economic growth. Often described as "neoliberalism," the new paradigm of power emphasizes the need to restore risk and responsibility to individuals, firms, and communities. Although much of the New Deal order remains intact, economic and legal policy produced since the 1970s has mostly sought to disaggregate society and re-establish the individual as the locus for decision making in all areas of life. No major expansion of social welfare has been successful since Medicare in the $1960 \mathrm{~s}$, and in many fields including pensions, insurance, and assistance to the poor, new mechanisms that empower individuals to control their own investment decisions but also retain substantial amounts of risk have become the norm. ${ }^{14}$

As one of the constitutive "social problems" of modern societies, crime is almost inevitably a central forum where fundamental transformation in governance is likely to show itself. This is certainly true of both the 1930s and more recent years. Although economic crisis rather then

13. Perhaps underscored by President Bill Clinton's statement in his 1996 State of the Union address that "[ $t]$ he era of big government is over." William Jefferson Clinton, 1996 State of the Union Address, January 23, 1996, available at http://www.washingtonpost.com/wp-srv/politics/special/states/docs/sou $96 . \mathrm{htm}$ (last visited December 3, 2003).

14. Tom Baker \& Jonathan Simon, Introduction, in Embracing Risk: The Changing Culture of Insurance and Responsibility 1 (Tom Baker \& Jonathan Simon eds., 2002). 
crime became the most important battle ground in the 1930s, crime might well have become a far more important issue. Our present conjuncture, in contrast, is one where crime has become one of the defining issues in which debate about the role and nature of government is carried out. $^{15}$

Herbert Wechsler's work on criminal law reflected in part, I would argue, his concern for the problems of democratic government in general, and in particular, the challenges of the New Deal. This concern shaped his subsequent contributions, especially the MPC, which achieved its more or less complete form in 1962, just as the New Deal epoch was about to enter a period crisis. The success of the MPC as a source of criminal lawmaking in the twentieth century was due in large part to Wechsler's focus on governance. It is hard to defend the MPC as a brilliant piece of criminal law theory. Indeed several generations of very smart law professors have made careers of pointing out its shortcomings. Far less did the MPC constitute an attempt to capture popular political sentiment about crime, in the way recent legislation like three-strikes laws can be understood. ${ }^{16}$ Wechsler and his colleagues considered popular expectations of criminal law as a kind of limit to their project, but they hardly viewed it as their mission to advance that popular expectation. If we can consider the MPC successful (a fair judgment in my view) it is because Wechsler, perhaps more than any of his academic competitors, understood the importance of modernizing criminal law in the light of the problems of democratic government, particularly the revolution in the structure of governance carried out by President Franklin

15. At least that is the thesis I argue for in a recent book manuscript, Jonathan Simon, Governing through Crime: The War on Crime and the Transformation of American Values, 1960-2000 (forthcoming Oxford University Press 2005).

16. Franklin E. Zimring et al., Punishment and Democracy: Three Strikes and You're Out in California (2001). 
Roosevelt and the New Deal Democratic party he created at the outset of Wechsler's career. ${ }^{17}$

The current interest of the ALI in redrafting important sections of the MPC's correctional code provides one sign of an awakening to the need to re-establish meaningful limits to the power to punish. In the remainder of this essay I want to contrast what might be called the political agenda ${ }^{18}$ of criminal law reform in Wechsler's era with the conjuncture we now find ourselves in.

\section{WECHSLER'S CENTURY 1937-1985 ${ }^{19}$}

The genesis of the $\mathrm{MPC}^{20}$ lies in a pair of articles coauthored by Wechsler and Jerome Michael, his senior colleague at Columbia Law School, and published in that school's prestigious law review in 1937: "A Rationale of the Law of Homicide, Pts I and II."21 The articles are a virtuoso piece of legal writing in the sweep of their scholarly research and theoretical reach, addressing not only the

17. Both Sanford Kadish and Sir Leon Radzinowicz link the MPC to the political context of the 1960s and the broad spirit of social reform pursued by the Kennedy and Johnson administrations. See Kadish supra note 7, at 949; Radzinowicz, Herbert Wechsler's Role in the Development of American Criminal Law and Penal Policy, 69 Va. L. Rev. 1, 8 (1983). The completion of the MPC and its legislative success may well reflect that decade, but Wechsler's vision of reform was cast decades earlier during the 1930 s in the political context of the New Deal. The sequence makes political sense as well since Kennedy's New Frontier and Johnson's Great Society initiatives were both efforts to recapture the momentum of the New Deal.

18. I do not mean so much Wechsler's policy preferences but rather his concerns with the revolution in governmental rationality that was taking place during the New Deal and specifically his concerns for how that revolution would affect and be affected by criminal law.

19. My centuries only include about fifty years. The starting point is the year that Wechsler published his pivotal article first outlining his reform vision later realized in the MPC. The ending point is the year the final revisions of the MPC were published and just as the production of the United States Sentencing Guidelines, a major step away from the vision of the MPC, was getting underway.

20. Kadish, supra note 7 , at 948 , describes it as "the indispensable first step to comprehensive reform."

21. Herbert Wechsler \& Jerome Michael, A Rationale of the Law of Homicide: I, 37 Colum. L. Rev. 701 (1937); Herbert Wechsler \& Jerome Michael, A Rationale of the Law of Homicide II, 37 Colum. L. Rev. 1261 (1937). 
common and statutory law of homicide but a good deal of the relevant human science literature of its time. Little is said expressly about politics or governance.

We are fortunate to know something about Wechsler's political priorities because in the very same year he published a more essay-like piece in the Journal of Criminal Law and Criminology, the chief organ within academic law of the movement to fuse social science and legal knowledge in the subject of crime and criminal law. ${ }^{22}$ Wechsler's essay, which appeared in the same year as the Columbia Law Review pieces, engages in some very specific criticism of politicians like Herbert Lehman and J. Edgar Hoover. The "Caveat" offers a glimpse of Wechsler's political concerns in reshaping criminal law.

Drawing on the "Caveat" we can see a number of issues that seem to weigh on Wechsler as he reflects on the currency of the criminal law in the midst of a governmental revolution, and the problems it poses for criminal law and criminal justice.

\section{A. High Crime Society ${ }^{23}$}

The 1920s saw the rise of gun violence around the illegal traffic in alcohol made possible by the adoption nationwide of Prohibition by the 18th Amendment to the Constitution in 1919. Although Prohibition was repealed in the very first year of Roosevelt's administration by the

22. Wechsler, Caveat, supra note 1. Michel Foucault helped make famous for a while an obscure essay of Kant's called in English, "What is the Enlightenment?" that had been published in a newspaper and intended for a general reading audience (albeit of 17 th century readers). See, Michel Foucault, What is Enlightenment?, in Ethics: Subjectivity and Truth 303 (Paul Rabinow ed., Robert Hurley et al. trans., 1997) In a similar vein I would like to make this short and more self consciously journalistic piece by Wechsler better known.

23. David Garland uses the phrase "high crime societies" to describe the condition of countries like the United States and Great Britain since the late 1960 s when he suggests a combination of cultural and social change led interpersonal crime to return to far higher levels than 20th century norms prior to that. David Garland, The Culture of Control: Crime and Social Order in Contemporary Society 139 (2001). In their own way the 1920s and 1930s also experienced high levels of public concern about crime. 
21st Amendment, the continuation of violent crime through the rest of the decade suggested that the criminal underworld invested by Prohibition had not disappeared with its repeal but had moved on to a host of criminal occupations including bank robbery, illegal gambling, loan sharking, union manipulation, and narcotics. A public suffering from the extreme economic privations of the Great Depression was simultaneously fascinated and horrified by what seemed to many a rising tied of crime.

One measure of this public concern was the rising level of imprisonment. These are the years that see the first great spike in U.S. imprisonment rates for which the federal government had begun to collect statistics beginning in $1925 .{ }^{24}$ After beginning very low in the first years in which federal data became available, in 1925, with about 9 prisoners for every 100,000 adult residents, the rate begins to climb to a high of 137 in $1939 .{ }^{25}$ In this period the great penitentiaries, some built as recently as in the 1920 s with ambitions to deter Prohibition-era crime, begin to become chronically overcrowded. ${ }^{26}$

The increased prison population reflected both public support for tougher measures against crime and the difficulties posed by the economic crises for reintegrating prisoners into the community. Members of the criminal underworld in this period had little opportunity to desist with employment remaining at catastrophically poor levels throughout the mid-1930s. It was in this era that bank robbers like John Dillenger and Bonnie and Clyde emerged as national crime celebrities with broad and largely fawning national followings. A police establishment, enlarged by Prohibition, remained in place and in search of new reasons to exist. The federal government's "Bureau of Investigation" and its ambitious director, J. Edgar Hoover,

24. The Commission on Observance of Law, popularly known as the Wickersham Commission, marked the emergence of criminal law as a major concern for the federal government.

25. Sourcebook of Criminal Justice Statistics 2001494 (29th ed. 2001), available at http://www.albany.edu/sourcebook (last visited December 3, 2003).

26. Charles Bright, The Powers that Punish (1996). 
played into the growing media sector of radio and newspapers and gave law enforcement a national celebrity profile. Meanwhile prison releases were mainly regulated by parole agencies required to establish that former prisoners would remain working and crime free if allowed release prior to the end of their lengthy or indefinite maximum sentence. ${ }^{27}$

In the "Caveat," Wechsler recognized the need for criminal law to be a more effective instrument against the kinds of crime, especially violence, that most trigger public concern. The twin problems of violent crime and a growing prison population fueled by fear needed to be addressed by a criminal law that was more preventive in focus. Among other things this required moving lawmakers beyond a focus on the existing crimes that generate public concern and towards a preventive law that operates against the precursors of violent crime.

If the law is to achieve its maximum efficacy in preventing, for example, physical violence, it is not sufficient merely to make it criminal to cause such violence intentionally, or even negligently. Behavior must be singled out which makes violence probable in the long run or identifies individuals who are dangerously likely to cause it; and it must be made criminal regardless of the results in the particular case. Thus reckless driving is criminal, and, on the same theory, so are attempts, solicitation, conspiracies and various kinds of assembly and disorderly conduct. ${ }^{28}$

The MPC would pursue this line, crafting attempt, solicitation, and conspiracy provisions aimed at eliminating common law obstacles to the prosecution of those with dangerous intentions.

27. Jonathan Simon, Poor Discipline: Parole and the Social Control of the Underclass, 1890-1990 (1993). It is perhaps only the power of labor scarcity during World War II's "total war" that pulled large portions of this incarcerated and underworld population into legal labor markets and viable lifestyles outside of the penal-correctional system. The overt anxieties about deviance in the $1950 \mathrm{~s}$ lifted incarceration rates again but by the $1960 \mathrm{~s}$, incarceration rates were on their way down to a 20 th century low in 1972 .

28. Wechsler, Caveat, supra note 1 , at 632 


\section{B. Populism and Professionalism}

In the very opening paragraphs of the "Caveat," Wechsler emphasized two features of crime control in his present that particularly disturbed him: populism and the exaggerated claims of crime control experts. Wechsler noted that "[p]ublic interest in the prevention of crime has increased tremendously in the last two years" but also that criminal justice professionals were making misleading claims to having expertise "adequate, or nearly adequate, to solve the practical problems of crime control."29

While we often think of populist pressures on the criminal justice system as in conflict with aspirations of professionalism, ${ }^{30}$ Wechsler viewed them as engaged in a dangerous spiral of expectations. Wechsler saw that public attention to the crime problem in the 1930s was being stimulated by the claims of law enforcement and other criminal justice professionals. This constellation was being further energized by politicians like J. Edgar Hoover and Thomas Dewey who were building public careers as effective crime fighters by playing to an "impressive series of newspaper and motion picture glorifications" of crime control. $^{31}$

Wechsler felt that law was particularly endangered by the twin pressures of populism and professional hubris (associated with the human sciences). Many Americans, Wechsler assumed, took Hoover's "Bureau of Investigation" to be the main function of the Department of Justice. ${ }^{32}$ This cycle of expectation could easily lead to massive disappointment with reactionary effects.

[O]versimplification of the problems of crime and of the criminal law has led the public to expect results that the criminal law machine will never produce, may lead to the uncritical acceptance in the name of crime control of

29. Id. at 629

30. Garland, supra note 23.

31. Wechsler, Caveat, supra note 1 , at 629.

32. Id. 
measures that are profoundly unwise and will make it progressively more difficult to direct popular enthusiasm along the most productive channels. ${ }^{33}$

Wechsler recognized that the populist media was both a challenge and a promise. After all, New Deal politics relied on communicating to a mass audience as Roosevelt so effectively did in his radio address. In the long run the substantive criminal law must help educate the public as to the very expectations they should have. The legitimacy of the criminal law must not depend on the raw results of crime control. A reformed criminal law must encourage expectations not of decreasing crime rates, but of rules and procedures that effectively balance competing considerations and produce a meaningful scaling of effort to the interests endangered by crime.

\section{Organized Crime and Organized Society}

The increasing public concern about crime that Wechsler described, along with the growing incarceration rate, made the boundaries of criminal law and its capacity to grade punishments among distinct cases critical issues for government. In retrospect the New Deal has been seen as a great success. The decades have smoothed away the turbulence of each year of the 1930s. Even with Roosevelt's legislative success, the recovery of the economy was never fully apparent in those years. Voices on the left and the right continued to call for even more dramatic changes in the nature of government.

The "Caveat," on my reading, has a background concern with the danger that criminal law might emerge as an effective avenue for political leaders to stay ahead of increasingly volatile public expectations. Even its supporters, like Wechsler, understood that the New Deal involved a tremendous expansion in the power and role of government over the lives of individuals. A New Deal

33. Id. at 630 . 
redirected into a massive war on crime, with expanded police and police powers could have looked all too much like Fascist Italy, Nazi Germany, and Stalinist Russia (which its opponents already compared it to).

Thus proposals for universal finger-printing, more extensive powers of arrest, search and examination, simpler extradition procedures, ... raise dilemmas as serious as those presented by the substantive law. Such measures may make it easier to catch criminals; they may also achieve other results ranging from the industrial blacklist and the shooting of wrongly suspected persons to the facilitation of a fascist coup d'etat. ${ }^{34}$

But this concern for a dangerous expansion of the criminal law did not lead Wechsler to endorse a significant reduction in the reach of the criminal law-far from it. In the pair of Columbia Law Review articles published the same year, Wechsler and his colleague Jerome Michael had laid a reform agenda aimed at improving the efficiency with which the criminal law responded to dangerousness or criminal propensity. While dubious about the aggressive new legislation being promoted against "professional criminals" by the likes of Hoover, Wechsler recognized that organized crime posed a greater danger to the legitimacy and democratic accountability of New Deal style government than it had in the past.

Organized crime, or racketeering as it was then called, was particularly threatening not because it was antithetical to the structures of power being forged by New Deal governance, but precisely because it fit so well. The growth of collectivist institutions like unions, employer associations, and consumer groups easily blurred with the image of criminal conspiracies, and these new economic units were in fact quite vulnerable to predatory invasion by organized crime.

Moreover, the ethnic communities associated both in popular culture and arrests with organized crime, Italians

34. Id. at 635 . 
and Jews, were key parts of the New Deal political constituency. To the critics of the New Deal, it would not be hard to see Roosevelt in alliance with Jewish and Italian racketeers. Indeed, from the perspective of laissez faire individualism, which had been the predominant political rationality of American capitalism, the New Deal may have seemed a kind of organized crime on a grand scale. It is not hard to imagine a deformed version of the New Deal that would have involved direct cooperation with gangsters, perhaps along the lines of Peronism in Argentina. ${ }^{35}$

Wechsler acknowledged this proximity in describing the danger that the wrong kind of attack on organized crime could sweep in the kinds of activity necessary to sustain the broader social transformation at stake in the New Deal. One feature of this problem was that effective techniques against professional criminals could also be used against social forces engaged in social struggle over the direction and nature of government.

[T] he broader and more effective such measures are as weapons against the professional criminal, the greater also is the danger that they will be employed against strikers, labor organizers, political reformers and others who may incur the displeasure of the police. ${ }^{36}$

The very transformations in political rationality going on in the 1930s meant that the very nature of social activity becomes more indeterminate.

[A] capitalist economy often posits difficulties in distinguishing "racketeering" activity from clever financing, the exploitation of new opportunities, shrewd competition or

35. In the 1948 movie, State of the Union, directed by Frank Capra, an inspiring industrialist, played by Spencer Tracey, is vetted as a potential candidate for the Presidency by the political professionals. State of the Union (Liberty Films 1948). The candidate meets in a smoke filled room with a bunch of ethnically stereotyped "pressure group" leaders who demand that he commit himself to their spoils system. In the pivotal scene the candidate defies this leadership by giving a speech calling for a return to government for the common good and against the special interests.

36. Wechsler, Caveat, supra note 1 , at 632 . 
even aggressive labor leadership. Not all of these difficulties are overcome by Mr. Dewey's definition of racketeering as "the systematic extortion of money through intimidation by an organization conducted for that purpose" ... ${ }^{37}$

Criminal law must be modernized so as to fit more appropriately into a more activist model of governance at the federal, state, and local level. At the same time Wechsler clearly envisioned a subordinate role of criminal law to the new forms of social solidarity being promoted by the New Deal's economic policies.

Man becomes good socially by being good individually and the general means to individual goodness are education, freedom from economic and physical handicaps, and the opportunity to function and be of service.... [T] he most satisfactory method of crime prevention is the solution of the basic problems of government-the production and distribution of external goods, education and recreation. ${ }^{38}$

Indeed, as the economic management and social integration of American society progressed, the burden of criminal law to maintain social order would lessen.

\section{Law and Social Science}

The integration of law and social science began well before the New Deal, and the criminal law was a central arena for competition between experts in the two fields. In Europe the battle between criminologists and jurists over whose knowledge of crime should guide the government was fierce. In the U.S. there was less sense of a zero sum game and more optimism about the combination of the two. Many leading progressive lawyers saw the social sciences as leading criminal law to an entirely new foundation. The leading criminal law professor of the first third of the

37. Id. at $632-33$.

38. Id. at 636-37. 
twentieth century, Roscoe Pound, believed that the reform of criminal law was largely irrelevant as progress in science would soon sweep existing doctrines away and construct a new rationality fit for an urban society.

The New Deal was in many ways a major advance for the alliance of law and the social sciences. Many New Dealers shared Pound's view that science and scientifically guided treatment would guide crime policy. ${ }^{39}$ Throughout the "Caveat," Wechsler expresses a skepticism of criminological expertise. Whether part of a broader skepticism about the human sciences or not, ${ }^{40}$ Wechsler saw the claims of human science to define criminal law as a grave danger to democratic government. One reason was the inflaming of populism discussed above, but another was the inherent instability of scientific knowledge for a system of norms that required broad consensus to operate effectively.

In the 1937 Columbia Law Review articles, Wechsler and Jerome Michael had devoted innumerable footnotes and whole sections to discussing the human sciences, but with the upshot of tracing a model of criminal law dependent not on the positive knowledge of science but precisely on its uncertainty. This strategy carried over into the MPC, which embraces a scientifically oriented treatment philosophy when it comes to penal practices but insists that substantive criminal rules be shaped by analytic exploration of the interests protected by criminal law. The expertise needed to steer such a system requires not so much awareness of positive scientific knowledge

39. Justice Douglas's concurrence in Robinson v. California 370 U.S. 660,668 (1962) (Douglas, J. concurring), is a strong if late example of the kind of expectation for the human sciences that New Deal legal theorists often had. Douglas cited extensive human science scholarship on drug addiction and praised the British approach to treating addiction as a medical matter in support of the Court's decision striking down a California law penalizing addiction.

40. In an oral history of Wechsler published in 1983, Wechsler expressed strong skepticism about the legal realism that was a center of controversy during his student days at Columbia in the late 1920s. See Norman Silber \& Geoffrey Miller, Toward "Neutral Principles" in the Law: Selections from the Oral History of Herbert Wechsler, 93 Colum. L. Rev. 854 (1993). 
about behavior but skills of analytic precision and interestbalancing long thought to be a virtue for lawyers.

\section{E. Wechsler as New Dealer}

No doubt Wechsler's vision of criminal law was insufficiently collectivist for some New Dealers, but in broad form it offered, in my view, a supportive reform agenda aimed at reducing the risk of an authoritarian turn in the New Deal led by a moral panic about crime and an expansion of policing power, and reducing the pressure that crime itself was placing on the collectivist impulses of the New Deal's "solidarity project." ${ }^{31}$ The MPC protected the individual as subject of government, but subtly expanded the capacity of criminal law to focus on dangerousness and criminal propensities in the name of social defense. The MPC also shared the New Deal preference for the political branches over the courts. In that respects it paralleled the central thrust of the New Deal to preserve the essentially liberal nature of the American political order while modernizing the capacity of government.

\section{OUR CENTURY, 1971-2019}

The beginnings of a new project to revisit features of the Model Penal Code, particularly those relating to sentencing and corrections, provide an occasion for reflecting in the spirit of the "Caveat" on the current period of governmental transformation. The MPC was published in preliminary draft in 1962 just as the Kennedy administration seemed poised to both reform and expand the New Deal political rationality. The final revision was

41. Garland, supra note 23, at 199.

42. I take my beginning point from the death of revolutionary prisoner George Jackson in a shoot-out at San Quentin prison in 1971. Jackson exemplified the hopes of the treatment model of modern punishment, an uneducated robber who became a bestselling author in prison (but also a violent revolutionary). See Jonathan Simon, Visions of Self Control: Fashioning a Liberal Approach to Crime and Punishment in the Twentieth Century, in Looking Back at Law's Century 109 (Austin Sarat et al. eds., 2002). The ending year is simply fifty years out. 
published in 1985 just as the re-election of President Ronald Reagan was consolidating a major movement to revisit and reject aspects of the New Deal. This movement with its stress on dismantling broad systems of social solidarity in favor of individual initiative and responsibility has worked a sweeping alteration of the New Deal project. Dramatic changes in tax policy have made the affordability of major social insurance programs increasingly problematic and the New Deal strategies of progressive taxation and extensive expert-based regulation of industry have been abandoned by both political parties. ${ }^{43}$ Like Wechsler, we might ask how this transformation is confronted by crime and crime control, and how an academic project of reform can usefully address this conjuncture.

One thing that is clear is that this time crime has played a significant role in the political struggle over the forms of governance. The New Deal project was attacked along a number of lines during the 1970s, 1980s, and 1990 s, but none so persistently and effectively as the claim that New Deal government was conducive to encouraging criminal lifestyles (the major criticism of welfare) and too soft on crime. I have argued in a recent book manuscript that crime control has become the central locus around which the recasting of American governance has taken place, but even if one does not choose to go that far, it is undeniable that crime and fear of crime have been distinctive features of the American road to neoliberalism. ${ }^{44}$

When Wechsler wrote in 1937, the rate of American adults imprisoned was 118 per 100,000 free residents, approaching a high of 137 per 100,000 free residents in 1939 , a level not attained again for nearly forty-five years. ${ }^{45}$ A new rise, beginning in 1973 from 93 per 100,000 free

43. This part of the meaning of President Clinton's proclamation in 1996 that the "era of big government is over."

44. Simon, supra note 15 .

45. Sourcebook of Criminal Justice Statistics 2001, supra note 25, at 494. 
residents, had reached 470 per 100,000 in $2001 .^{46}$ In the $1930 \mathrm{~s}$, the loosely coupled criminal justice system could easily drain away correctional population pressures once plausible non-criminal activities were available to prisoners on the outside, conditions that began to apply as the wartime economy heated up in the early 1940s. In the 1990s, tight labor markets run together with high incarceration rates. ${ }^{47}$

In the remainder of this essay I want to follow Wechsler, not in his New Deal-based strategy for criminal law, but in his ambition in the "Caveat" to understand the reform of the criminal law from the perspective of the profound changes in the basic rationalities of government.

\section{A. Mass Incarceration}

The prison, in my view, is not one of the dark moments of contemporary civilization. There are better places to murder people and abuse their human rights. The very panopticism of the prison lends itself to enforcement of norms and accountability. ${ }^{48}$ The challenge at the moment is not incarceration but the rise of mass incarceration. The penitentiary became a crucial regulatory institution in the industrial "mass society" that took shape in the twentieth century. ${ }^{49}$ In many respects the prison operated to preserve the liberal character of mass society by operating on individuals who failed in a range of softer institutions. ${ }^{50}$ The capacity of peno-correctional modernism, and the prisons shaped by it to "rehabilitate" criminal convicts, remains difficult to assess in retrospect, ${ }^{51}$ but its aspiration

46. Id.

47. Theodore Caplow \& Jonathan Simon, Understanding Prison Policy and Population Trends, in 26 Crime \& Just. 63 (Michael Tonry \& Joan Petersilia eds., 1999).

48. Michel Foucault, Discipline and Punish: The Birth of the Prison (Alan Sheridan trans., 1977).

49. James B. Jacobs, Stateville: The Penitentiary in Mass Society (1977).

50. Charles Bright, The Powers that Punish: Prisons and Politics in the Era of the "Big House," 1920-1955 (1996).

51. When criminologists and policymakers turned a critical eye on 
to do so was explicit and ran deeply into the organization of the prison.

Today we are experiencing something different, imprisonment on a mass basis of whole portions of the population with little aspiration to individualize or reclaim. $^{52}$ Mass imprisonment abandons the individual as a target of penal power in favor of dangerous classes. The careful calibration of the social interest in sanctioning certain behaviors is replaced by a zero tolerance model in which those designated as dangerous are subjected to longterm containment on the model of waste management. Imprisonment remains a plausible if unpredictable strategy to deal with serious crime, but mass imprisonment promotes something different, the indiscriminate use of imprisonment as a response to even modest levels of criminality when they are associated with feared or despised groups.

Wechsler would have been affronted by this abandonment of individualized culpability in the assessment of worthiness for punishment. Reformers who would challenge the legal strategies underlying mass imprisonment would find in the MPC and its commentaries a weapon with which to challenge the legitimacy of mass imprisonment within the tradition of American penal law.

\section{B. Deep Populism}

Casting aside decades of association between modern sensibilities about punishment and utilitarian goals of crime control (whether through deterrence, rehabilitation, or incapacitation), contemporary penal law is full of the rhetoric of deserved suffering and even cruelty. The clear

rehabilitation in the 1970 s they found little hard evidence that penal treatment made a difference and the slogan "nothing works" became a widely shared perception. Garland, supra note 23, at 69 .

52. See Mass Imprisonment: Social Causes and Consequences (David Garland ed., 2001); see also Malcolm Feeley \& Jonathan Simon, The New Penology: Notes on the Emerging Strategy of Corrections and Its Implications 30 Criminology 449 (1992). 
sense of a trajectory toward less violent and less stigmatizing penal forms has been broken. Once promising forms of knowledge like psychology and criminology have been relegated to narrow roles in the criminal process. The primary influences on crime policy come not from science but from popular culture. Popular recent laws like "ThreeStrikes" and "10-20-Life" have been written and marketed by activists whose organizational background is in advertising, sales, and entertainment.

Contemporary criminal legislation is populist in two senses. First, its imagery is antagonistic to the expert claims of would-be academic reformers or criminal law codifiers; indeed they suggest that such expertise is as much the enemy of the law as crime itself. We can talk about the deterrence or incapacitative effects of ThreeStrikes Laws, or 10-20-Life, but this logic vastly underdetermines a penal architecture that has no deep faith in any such modern goals. The criminal law being produced by contemporary legislatures and Congress functions as a kind of aesthetic object designed to mirror the outrage and resentment that many Americans feel at the insecurities of life at the turn of the twenty-first century.

Second, the knowledge that is central to crime governance is increasingly popular whether picked up by community police officers doing surveys, prosecutors, victim impact testimony at sentencing hearings, or simply the political statements of victim advocacy groups. Here the differences with Wechsler's century are most striking. Populism then meant responding to public fears about professional criminals but with the guidance of experts and under the control of a strong state ready to assure the common good over private interests. Today a deep populism demands that the methods and rationalities of criminal law honor the truths of the common experience of victimization. This pervades not only the statements of politicians but the reasoning of Supreme Court justices. ${ }^{53}$

53. This begins as early as the dissents to Furman v. Georgia, 408 U.S. 238 
While positivist criminology and psychology promised to expose the truth of criminal propensity, today's legislators are interested in another kind of truth of crime, that of the victim who has become an idealized political subject for the contemporary period, defining the needs and rights that shape how government governs. The penal system does not need social sciences to get access to this kind of truth; instead, prosecutors and to some extent police have institutionalized themselves as representatives of the crime victim, a posture that dramatically contrasts with the modern twentieth century models of both institutions.

In all of these settings, crime has emerged as one of the most potent and versatile formations that can be brought into play. Consider family heads who find themselves simultaneously concerned with (and governing the risks of) the victimization of their family directly by crime (as in a mugging, burglary, or worse); the victimization of their family indirectly by declining home values and school conditions; the potential criminal conduct of their children toward teachers, other students, and the parent themselves; and the possibility that their own misconduct could be viewed as criminal (for abusive discipline).

While the war on crime played a crucial role in mobilizing the forms of capital necessary to transform crime into a master problem, the endurance of governing through crime is not necessarily tied to the continuing conduct of that war. It remains to be seen whether the long decline in violent crime rates most everywhere during the 1990s will lead to a substantial waning of the war on crime. Consider the Bush II administration. Hardly a peep was said about criminal justice issues during the Fall 2000 campaign against Democrat Albert Gore. ${ }^{54}$ Nonetheless,

(1972) and reaches its full expression with Justice Scalia's concurring opinion in Payne v. Tennessee, 501 U.S. 808, 834 (1991) (Scalia, J., concurring).

54. In pointed comparison to his father's landslide 1988 win against Michael Dukakis, Bush never was able or really tried to draw much difference between himself and Gore (who unlike Dukakis purports to support the death penalty strongly). 
even before 9/11, Bush and Attorney General John Ashcroft made clear their intent to rely heavily on crime including a renewal of the war on drugs, a strong effort to normalize the Texas model of routine capital punishment through the use of the Federal death penalty nationally, and pursuit of a right wing religious agenda through punitive regulatory treatment of physicians who assist suicide or prescribe controlled substances. Since $9 / 11$, the war on terrorism has closely tracked the war on crime including the familiar solutions of the death penalty, prisons (like the now semipermanent facility in Guantanamo Cuba), and dragnet style "interviews" of Muslims who are visiting the United States or have recently immigrated here from the Middle East. None of this should be a surprise of course given that both Bush and Ashcroft (the latter over a far longer political career) built strong identities as crime warriors.

Wechsler remained optimistic that a proper MPC would and could be marketed to an increasingly populist national public. Today it is very hard to be optimistic that a similar expert based reform proposal would be entertained by legislatures focused on victim speech.

\section{Reform in an Age of Catastrophe: Punishment and the Precautionary Principle}

One of the things criminal law reform had going for it in the era of the New Deal was the growth of solidarity-based governance which celebrated sharing risks across society in the name of reducing the overall suffering of the population. While crime as a social problem has proven to be a deep challenge to the logic of risk spreading, the rising tide of solidarity in the 1930s made it easier to imagine socializing the risk of crime through a penal system aimed at achieving a socially advantageous balance of risks. This meant increasing the risk of imprisonment for criminals whose conduct was discovered at an early stage but whose criminal intent was clear, but also a correctional strategy of early release or probation for those convicted of serious criminal acts whose individual prospects for rehabilitation were good. 
Efforts to recast criminal law in the present face a dramatically different political culture of risk, one that has already placed its imprimatur on contemporary penality. Recently Francois Ewald has suggested that what he calls the paradigm of solidarity, characterized by broad efforts to socialize risk through social and private insurance, welfare, and ameliorative social policies, is breaking down. ${ }^{55}$ The solidarity paradigm arose in the late-nineteenth century around the problem of industrial work accidents. Solidarity replaced an earlier paradigm of risk, which Ewald calls providence, which treated accidents as aberrational to be treated either as acts of God, or the results of individual fault. The response was to provide compensation to truly innocent victims while leaving losses on those at fault. Solidarity, in contrast, recognized accidents as ordinary features of modern life to be actuarially predicted. The major social response was to address losses through compensation regardless of fault and ameliorate systematic losses through technology and regulation.

Ewald argues that the solidarity paradigm, which dominated social policies toward risk throughout the developed world during the twentieth century, is being increasingly discredited in the face of new kinds of threats that do not seem addressable in terms of loss spreading and regulation. In place of the repetitive accidents, e.g., industrial injuries and automobile accidents, the developed world is increasingly politically focused on what Ewald calls "the return of disasters." 56 These new threats, terrorism, advanced technology disasters, and medical errors do not lend themselves to the dominant strategy of solidarity, i.e., compensating the victims regardless of fault. Moreover, while the solidarity paradigm placed great emphasis on scientific knowledge to predict the extent of losses and craft regulatory approaches toward ameliorating

55. Francois Ewald, The Return of Descartes's Malicious Demon: An Outline of a Philosophy of Precaution, in Embracing Risk: The Changing Cutlure of Insurance and Responsibility 273 (Tom Baker and Jonathan Simon eds., 2002).

56. Id. at 282 . 
them, the safety paradigm is informed by awareness of the uncertainty of scientific knowledge and the inability to predict certain kinds of catastrophic events. This lends itself to what has been called in environmental policy the "precautionary principle," i.e., the notion that when catastrophic losses are possible and scientific knowledge is uncertain the most appropriate risk policy is not to take the risk at all.

Crime, especially violent crime, has always been difficult to fit into a solidarity model of loss spreading. After all solidarity meant ignoring fault while crime is all about fault. Yet the high tide of the solidarity paradigm during the mid-twentieth century supported penal strategies of amelioration and risk sharing. Crime was subordinated to the model of the accident. With the return of disasters crime has come back into priority. Indeed, while Ewald's primary examples involve various kinds of medical and technological risk, violent crime, homicide in particular, provides a model of unspreadable loss. That is not simply the case for the primary victim, but today for the survivors as well. Their loss cannot be made up since it involves the creation of personal trauma.

The emergence of the safety paradigm makes it far more difficult to sustain such a modernist approach to criminal law. Instead, as we have seen in American criminal justice policy over the last couple of decades, the emphasis is on increasingly aggressive efforts at prevention through law enforcement, severe penalties, and private measures like gated communities and gun ownership. Where precaution fails and losses occur, the response is likely to be a demand for retributive justice.

The appearance of the precautionary principle is registered in the context of victims who are no longer satisfied with compensation, no matter how large, but who are only satisfied when those responsible are held criminally liable. ${ }^{57}$

57. Id., at 284. 
Indeed, while Americans have been rather less concerned than the Europeans about catastrophic environmental trends (global warming or the potential impact of genetically modified food), they have been far readier to see rape, murder, or child sexual abuse as a very real threat in everyday life as evidenced by gun sales, testimony in day care sex abuse conspiracy cases, and selfreporting by women college students. If Americans have avoided the precautionary principle in the environmental field we have adopted laws like Three-Strikes that embody the same concern focused on crime and criminals.

In contrast to the era in which the MPC was first produced, the accident no longer rules over crime, pointing the way toward the promise of compensation.

The appearance of the precautionary principle no doubt marks the limit of this equation and its underlying logic. With the irreversible we rediscover the irreparable. Not everything is a matter of economics. Not everything can be assessed a money equivalent. From now on, we no longer limit our attention to compensating, but are also concerned with preventing, forbidding, sanctioning, and punishing. A logic of responsibility returns alongside the solidaristic problematic of compensation. ${ }^{58}$

New efforts to reform criminal law in a systematic way operate in a dramatically different culture of risk in which crime has become the very model of catastrophic loss. This fits most classically with homicide, but we can see it proliferate into many other crimes that promise a little death, including drugs, sex crimes, and burglary among other crimes. The tenuous compromise with populism that runs through the MPC is possible because crime could be anchored against the broad capacity of the solidarity paradigm to define public life and lawmaking. As intolerable risks come to define risk management more generally, it is not surprising to see an intensification of punishment as the preferred response to a whole range of social problems. Under the precautionary principle "the

58. Id., at 285. 
decisionmaker is invited to expect the worst, the possible catastrophe, the irreparable . . . "59

\section{CONCLUSION: WECHSLER'S PROJECT AND OURS}

Wechsler's project for reforming criminal law, at least on my account, can be seen as motivated by the profound transformation of the New Deal in two ways: both by a recognition that the popular response to crime might endanger the democratic character of that profound transformation in government, and awareness that this transformation was creating a real opportunity to overcome traditional populist constraints on reform. Wechsler first outlined that reform program in his 1937 articles as the New Deal was consolidating its hold on power. The fruit of that reform, the Model Penal Code, was completed in most respects twenty-five years later as the New Deal seemed poised for further expansion.

The prospects for a comparable reform effort today are not nearly as positive, but the needs are as great. As before, the politicization of crime threatens to distort the transformation in governance now underway. Indeed, as I have argued elsewhere, efforts to recast American institutions are being influenced by the model of crime control at every level in ways that risk undermining both the objectives of transformation and the democratic character of our society. ${ }^{60}$ Mass incarceration is hardening the barriers that have traditionally burdened the participation of minority communities both directly through disenfranchising felons in many states and indirectly by reinforcing the economic isolation, social disorganization, and stigma associated with those communities.

Meanwhile the overwhelming influence that fear of crime has on the way Americans live, raise their families, and conduct their business is undermining the very

59. Id. at 287.

60. Jonathan Simon, Megan's Law: Crime and Democracy in Late Modern America, 25 Law \& Soc. Inq. 1111 (2000). 
direction of neo-liberal transformation. For example, the goal of decentralizing decision making by placing greater risk and responsibility on individuals, families, firms, and other communities, a central objective of neo-liberalism, is contradicted by the grip of crime fear which motivates greater reliance on law enforcement. Even when individuals take primary responsibility for crime prevention by moving to gated communities or placing their children in all-day managed settings, the rigidity and high costs exacted by these strategies makes less likely precisely the kind of efficient communication of knowledge and flexible response that are the promised fruits of reliberalizing social and economic life.

Although it is difficult to see how a similar academically informed reform project could survive the deep populism that currently dominates the legislative and policy process, there are some promising signs in the draft code of corrections and sentencing. One of the most promising is the focus on prison conditions. Mass incarceration can only seem a promising strategy for social defense when those portions of society made directly less secure by it are excluded from consideration. Those actually in prison, or at risk of going there, a group that now includes nearly three percent of adult Americans who are already in the formal custody of the correctional system, are directly effected by the kind of prison system that has emerged from mass incarceration. Their risks of suffering criminal violence by other prisoners or staff, or of suffering substantial degradation of their mental and physical health, economic value, and social status are made higher by the emergence of the warehouse-style prison built to hold prisoners in and do little else. That may be acceptable to the public for retributive reasons, but only if those suffering such risks are guilty of serious crimes. But mass incarceration involves the use of prison against persons whose crimes have not substantially endangered personal or property interests. ${ }^{61}$ By placing prison

61. See, for example, California's three strikes law upheld by the Supreme 
conditions within the same focus as sentencing policy, the proposed code creates the possibility of public visibility and accountability that could confront the public with the real costs of mass incarceration. ${ }^{62}$

Another strategy along similar lines would be to bring police procedures into the same field of consideration as penal policy. Recent innovations in DNA technology have led to a wave of disclosures of innocent people in prison and on death row. These revelations continue to be treated as fortuitous discoveries of unavoidable errors. But the leading champions of exoneration have insisted for some time that these discoveries are a window into systematic flaws in our policing and prosecution practices. ${ }^{63}$ Not only does this background of error raise questions of justice regarding the increasing severity of our penal policies, but these very policies, including mass incarceration, mandatory minimum sentences, and the resumption of capital punishment may actually have a perverse effect on law enforcement by creating incentives for misconduct and opportunities for easing the challenge on prosecution that can lead to the conviction of the innocent and the failure of police to arrest truly threatening criminals.

Court in Ewing v. California, 538 U.S. 11 (2003).

62. Ultimately because of the potential for interstate competition in mass incarceration it may be necessary to adopt a constitutional approach. My proposal, based roughly on the 14th Amendment is as follows:

Mass incarceration being destructive of the conditions of a democratic society, the right of the people to proportionate sentences shall not be infringed.

For purposes of apportioning representatives in Congress, the number of electors in each state shall be the total number of citizens above the age of 18 minus the total of such citizens incarcerated for sentences of 1 year or more by the state.

63. Barry Scheck et al., Actual Innocence : Five Days to Execution and Other Dispatches from the Wrongly Convicted (2000). 